\title{
Analysis and Management of Brain Abscess; A Ten Year Hospital Based Study
}

\section{Beyin Apsesi Analizi ve Takibi; On Yullı Hastane Tabanlı Bir Çalışma}

Arif Hussain SARMAST, Hakim Irfan SHOWKAT, Abdul Rashid BHAT, Altaf Rehman KIRMANI, Mohammad Yousuf KACHROO, Suhail Farooq MIR, Yasir Ahmed LONE, Aamir Aalam KHAN

Sher I Kashmir Institute of Medical Sciences Srinagar, Department of Neurosurgery, Srinagar, Jammu and Kashmir, India

Correspondence address: Arif Hussain SARMAST / E-mail: arifhsarmast@gmail.com

\begin{abstract}
AIM: To study Clinical , microbiological and radiological profile of pyogenic brain abscess patients along with modes of treatment and their outcome.

MATERIAL and METHODS: This retrospective as well as prospective study included One hundred and fourteen patients of Brain Abscess who were admitted and evaluated in the Department of Neurosurgery over a period of ten years. This study had a retrospective component from Oct 2001 to May 2009 in which eighty six patients were included and a prospective component from June 2009 to Oct 2011 which included twenty eight patients. Patients were managed medically including intravenous antibiotics and surgical management including single burr hole and total resection with open craniotomy or craniectomy. To evaluate abscess size after aspiration, CT or MR imaging was performed [ 24 hours after aspiration] and as and when demanded by worsening of the clinical condition or no response to medical and surgical treatment. RESULTS: It was observed that majority of the patients in our study were males numbering $83(72.8 \%)$ where as there were only 31 females (27.2\%). It was observed that among the underlying factors CSOM predominated with 57 patients ie (50\%).
\end{abstract}

KEYWORDS: Brain, Abscess, CT Scan , MR imaging

ÖZ

AMAÇ: Piyojenik beyin apsesi hastalarında klinik, mikrobiyolojik ve radyolojik profili tedavi modları ve sonuçlarıyla birlikte çalışma.

YÖNTEM ve GEREÇLER: Bu retrospektif ve prospektif çalışmaya on yıllık bir süre içinde Nöroşirürji Bölümüne kabul edilip değerlendirilen yüz on dört hasta alındı. Bu çalışmanın Ekim 2001'den Mayıs 2009'a kadar retrospektif bir bileşeni vardı ve buraya seksen altı hasta dahil edilirken Haziran 2009'dan Ekim 2011'e kadar olan prospektif bileşene yirmi sekiz hasta dahil edildi. Hastalar intravenöz antibiyotikler dahil tıbbi tedaviyle ve tek burr deliği ve açık kraniyotomi veya kraniyektomi ile total rezeksiyon dahil olmak üzere cerrahi tedaviye takip edildi. Aspirasyondan sonra apse büyüklüğünü değerlendirmek için [aspirasyondan 24 saat sonra] ve klinik durumun kötüye gitmesi ayrıca tıbbi ve cerrahi tedaviye cevap alınmaması nedeniyle gerektiği şekilde BT ve MR görüntüleme yapıldı.

BULGULAR: Çalışmadaki hastaların çoğunun erkek olduğu görüldü ve 83 erkek $(\% 72,8)$ ve sadece 31 kadın $(\% 27,2)$ vardı. Altta yatan faktörler arasında CSOM durumunun 57 hastayla ön planda olduğu saptandı (\%50).

ANAHTAR SÖZCÜKLER: Beyin, Apse, BT Taraması, MR görüntüleme

\section{INTRODUCTION}

Fulminant intracranial infection is, along with trauma, perhaps the oldest disease process that has required neurosurgical intervention. Trephines on archaeological skulls as well as medieval artistry document the early attempts of treatment of the patient with mental status changes, infections and localizing neurological signs (17). Despite the advent of modern neurosurgical techniques including stereotactic brain biopsy and aspiration, better anaerobic culture techniques, new antibiotics, and modern noninvasive neuroimaging procedures, brain abscess remains a potentially fatal central nervous system infection. Recent advances in early diagnosis and treatment have improved its prognosis $(5,18)$.

\section{MATERIAL and METHODS}

The study, "Analysis and management of Brain Abscess-a ten year hospital based study" is an eight year retrospective study from October 2001 to May 2009 and prospective study from June 2009 to October 2011. This study was carried out in Department of Neurosurgery Sher-i-Kashimir Institute of Medical Sciences Srinagar (SKIMS) which has a neurosurgical unit for both adults and pediatric cases, and is the reference centre for a population of almost ten million people. The study included all the patients presenting to or referred to the Department of Neurosurgery with a likely diagnosis of brain abscess. A detailed history and a thorough physical examination of each patient was carried out including age, sex, residence, presenting complaints with special stress on headache, nausea, vomiting, level of consciousness using 
standard Glasgow Coma Scale, seizures, hemiplegia, speech disturbance, visual disturbance and other minor neurosurgical disturbances. Various laboratory tests, including a complete blood count, erythrocyte sedimentation rate, [pre-op/postop/follow up], blood cultures, and serum chemistry, chest Xray P/A view and an ECG were performed. Preoperative $\mathrm{CT}$ scans were obtained in all patients. MR imaging was performed whenever diagnosis was in doubt.

A diagnosis of brain abscess was considered definite if;

1. The organism was isolated from the pus itself or CSF cultures.

2. CT Scan showed findings characteristic of brain abscess.

3. The classical clinical manifestations occurred including headache, fever, localizing neurological signs or disturbance of consciousness.

4. In other patients confirmation was obtained from the disappearance of CT abnormalities after antibiotic treatment.

The patients with tubercular meningitis, tubercular abscess, subdural empyema, extradural abscess were excluded from the study.

The patients were categorized for reception of forms of treatment like medical treatment alone or in combination with one or other surgical mode of management. Small acute and subacute stage brain abscesses (defined as $<2.5 \mathrm{~cm}$ in mean diameter) without consciousness disturbance and in early stage of evolution were treated using antibiotics alone. Surgery was performed when CT/MR imaging demonstrated an intracranial large brain abscess formation in capsular stage, presence of significant mass effect, high intracranial pressure, proximity to ventricles and possibility of ventricular rupture, posttraumatic abscesses containing foreign bodies or contaminated bone fragments, poor response to medical treatment, deterioration in neurological status, or enlargement of abscess volume during medical treatment. Empirical intravenous antibiotics were started on suspicion of brain abscess and were changed to definite therapy as per the culture report. Antibiotic therapy was continued for $\geq 6$ weeks in accordance with the therapeutic response and neuroimaging findings. High-dose corticosteroid therapy (intravenous dexamethasone, given in a dosage of $8 \mathrm{mg} / 6$ hours) was commenced initially in patients with lifethreatening cerebral edema or impending cerebral herniation and was then tapered off. Antiepileptic medication was given in all cases and continued for extended periods. Patients underwent aspiration via a burr hole, or complete excision via craniotomy or craniectomy. Most patients underwent aspiration via a burr hole. After aspiration, CT or MR imaging was performed if new symptoms developed or symptoms worsened. To evaluate abscess size after aspiration, CT or MR imaging was performed [ 24 hours after aspiration] and as and when demanded by worsening of the clinical condition or no response to medical and surgical treatment. If the size of the abscess on CT or MR images obtained after the first aspiration increased or was not reduced despite antibiotic therapy, aspiration was repeated. Patients with poor response to repetitive aspirations and medical treatment underwent complete excision of abscesses through craniotomy or craniectomy. Posttraumatic abscesses containing foreign bodies or contaminated retained bone fragments, deepseated abscesses (for example, a cerebellar abscess), and postoperative abscesses where bur hole aspiration would hinder the fusion of bone flap also underwent complete abscess excision through craniotomy or craniectomy. Therapeutic outcome of patients was assessed by comparing with the pretreatment status and the status post treatment and post surgery. All the post operative and post-treatment complications were noted and recorded. Clinical and neuroradiological findings, treatment modalities, pus cultures and organisms grown, therapeutic outcomes were summarized.

Data collected as such was described as mean and percentage. MS EXCEL, SPSS MINITAB and JAVA STAT SOFTWARE was used for data analysis.

\section{RESULTS}

It was observed that majority of the patients in our study were males numbering $83(72.8 \%)$ where as there were only 31 females (27.2\%). Majority of our patients were adults ( $>18$ yrs of age) forming $73.7 \%$ of the studied population and $26.3 \%$ were children. It was observed that the commonest age group of our patients was 20-29 years, youngest patient being 6 months old and oldest patient was 70 years of age, with an average mean of 31.2 years. Majority of the patients in our study were from rural areas $89(78.1 \%)$ where as only 25 patients were from the urban areas i.e (21.9\%) as shown in Table I which shows age wise distribution of sex and dwelling of our patients.

Year wise trends didn't show any specific increasing or decreasing pattern of brain abscess patients. More than one symptom was seen in our patients, headache (71\%), nausea \& vomiting (64.9\%) and fever (51.8\%) predominated among others. Only seven of our patients i.e (6.1\%) had a low score on GCS (<13) whereas majority of our patients, 107i.e $(93.9 \%)$ were alert at the time of admission with a GCS $>13$.

It was observed that among the underlying factors CSOM predominated with 57 patients ie (50\%) having an underlying unsafe ear. Other underlying factors in order of frequency were post traumatic $11(9.6 \%)$, surgery head $10(8.8 \%)$, pulmonary disease $8(7 \%)$, sinusitis $6(5.3 \%)$, heart disease $4(3.5 \%)$ and adjacent local cranial infection 3(2.6\%). In 10 patients ie $(8.8 \%)$ no underlying factor could be identified and were thus labeled as cryptogenic. It was seen that among the patients who had CSOM as the underlying factor commonest organism isolated was streptococcus pneumoniae (39.2\%), streptococcus milleri (23.5\%), haemophilus influenzae (11.8\%), staphylococcus aureus (9.8\%), B haemolytic streptococcus 
Table I: Age Wise Distribution of Sex and Dwelling of Brain Abscess Patients

\begin{tabular}{|c|c|c|c|c|c|c|c|c|c|c|}
\hline \multirow{3}{*}{ Age (yr) } & \multicolumn{4}{|c|}{ Gender } & \multicolumn{4}{|c|}{ Dwelling } & \multirow{2}{*}{\multicolumn{2}{|c|}{ Total }} \\
\hline & \multicolumn{2}{|c|}{ Male } & \multicolumn{2}{|c|}{ Female } & \multicolumn{2}{|c|}{ Rural } & \multicolumn{2}{|c|}{ Urban } & & \\
\hline & $\mathbf{n}$ & $\%$ & $\mathbf{N}$ & $\%$ & $\mathbf{N}$ & $\%$ & $\mathbf{N}$ & $\%$ & $\mathbf{n}$ & $\%$ \\
\hline 0 to 9 & 10 & 12.0 & 4 & 12.9 & 13 & 14.6 & 1 & 4.0 & 14 & 12.3 \\
\hline 10 to 19 & 9 & 10.8 & 7 & 22.6 & 12 & 13.5 & 4 & 16.0 & 16 & 14.0 \\
\hline 20 to 29 & 24 & 28.9 & 5 & 16.1 & 22 & 24.7 & 7 & 28.0 & 29 & 25.4 \\
\hline 30 to 39 & 9 & 10.8 & 7 & 22.6 & 12 & 13.5 & 4 & 16.0 & 16 & 14.0 \\
\hline 40 to 49 & 10 & 12.0 & 5 & 16.1 & 13 & 14.6 & 2 & 8.0 & 15 & 13.2 \\
\hline 50 to 59 & 9 & 10.8 & 1 & 3.2 & 9 & 10.1 & 1 & 4.0 & 10 & 8.8 \\
\hline$\geq 60$ & 12 & 14.5 & 2 & 6.5 & 8 & 9.0 & 6 & 24.0 & 14 & 12.3 \\
\hline Total & 83 & 72.8 & 31 & 27.2 & 89 & 78.1 & 25 & 21.9 & 114 & 100.0 \\
\hline$P$ value & \multicolumn{4}{|c|}{0.182 (NS) } & \multicolumn{4}{|c|}{0.311 (NS) } & & \\
\hline
\end{tabular}

(7.8\%), staphylococcus epidermidis (2\%), pseudomonas aeruginosa (2\%), enterobacter spp. (2\%), klebsiella pneumoniae (2\%). In the post traumatic group largest representation was from staphylococcus aureus (36.4\%) followed by staphylococccus epidermidis (18.2\%), pseudomonas aerugonisa (18.2\%), enterobacter spp (18.2\%) bacteriodes fragilis\& peptostreptococcus combined at $(9.1 \%)$. In patients who had undergone some form of surgery in the head staphylococcus aureus was the commonest organism isolated (40\%) followed by staphylococcus epidermidis (30\%), pseudomonas aeruginosa (20\%) and enterobacter spp(10\%). In Cryptogenic group pseudomonas aeruginosa predominated at (72\%), followed by streptocococcus pneumoniae (14\%) and bacteriodes fragilis (14\%). Similarly one or more organisms were isolated from smaller groups.

Brain abscesses in adults were located in temporal region (28.6\%) followed closely by temporo- parietal region $(23.8 \%)$ [as shown in Figure 1], frontal region (10.7\%), cerebellar region (17.9\%), parietal region (6\%) [as shown in Figure 2], parieto-occipital region (9.5\%). There were 3 patients $(2.6 \%)$ who had abscesses at multiple places. Table II summarizes the number and location of abcesses as depicted by imaging (CT/MRI). In children the results were more or less same with an important finding that second common region of brain abscess in them was frontal region (26.7\%) exceeded only by temporal region (30\%). Among the abscesses located in the supra tentorial region 93 i.e (94.9\%) were solitary whereas 5 ie $(5.1 \%)$ were multiple. In the infratentorial region all the $16(100 \%)$ abcesses were single. The mean diameter of the abscess was $3.0 \mathrm{~cm}$ with smallest being $1.5 \mathrm{~cm}$ and largest abscess had the diameter of $5.4 \mathrm{~cm}$. The brain edema was present in 37 patients (32.5\%), while mass effect and midline shift was noticed in 22 i.e. (19.3\%) patients.

All the 114 patients in our study received empirical medical therapy as the first form of management, however in $14(12.3 \%)$ medical therapy was continued as the sole form of treatment. In 100(87.7\%) patients some form of surgery was

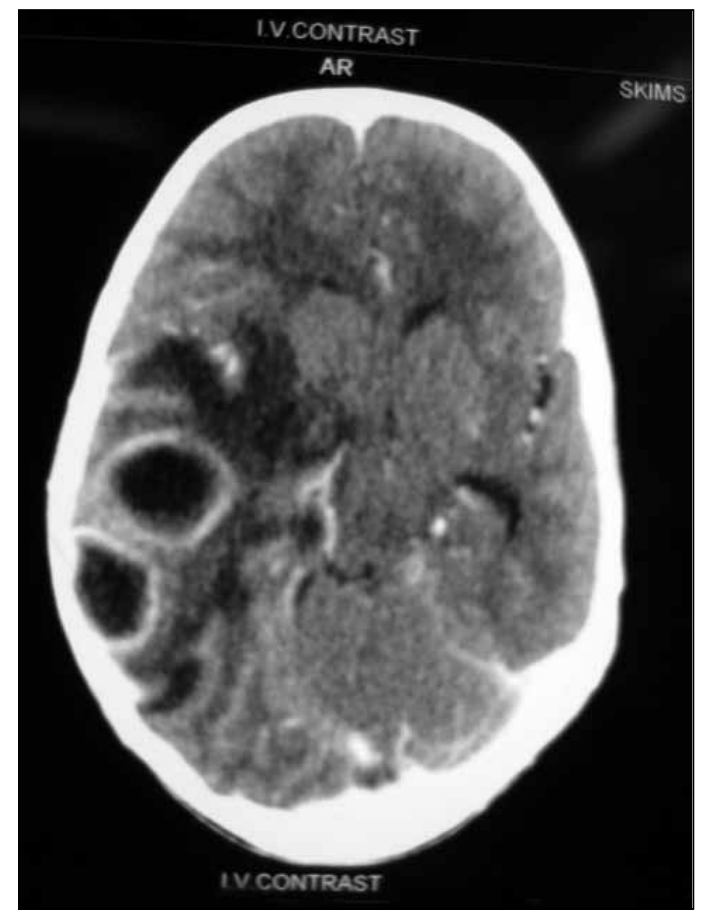

Figure 1: CECT Brain showing abscess cavities in the right posterior temporo parietal area.

added to the medical management already continuing. A total of $67(67 \%)$ patients received aspiration as a form of treatment after burr hole was made in the skull [as shown in Figure 3, $4,5]$, whereas $30(30 \%)$ patients underwent excision of their brain abscesses, 3 (3\%) patients received aspiration followed by excision of the brain abscess in combination. Among the 70 patients who underwent aspiration of their brain abscess 51 i.e. (72.9\%) underwent aspiration once only, 18 patients (25.7\%) had to undergo aspiration twice whereas in a Patient aspiration was repeated three times. It was observed in our series that 93 patients $(81.57 \%)$ had a positive culture while as 21 patients (18.42\%) did not grow any bacteria on culture. 
Most of our cultures were pure that is 89(95.7\%) and grew only a single organism where as 4 cultures grew 2 organisms. The commonest organism grown was streptococcus pneumoniae 23 (26.4\%) followed by staphylococcus aureus 15 (17.2\%), streptococcus milleri 12 (13.8\%) pseudomonas aeruginosa 12 $(13.8 \%)$ and others in smaller percentages.

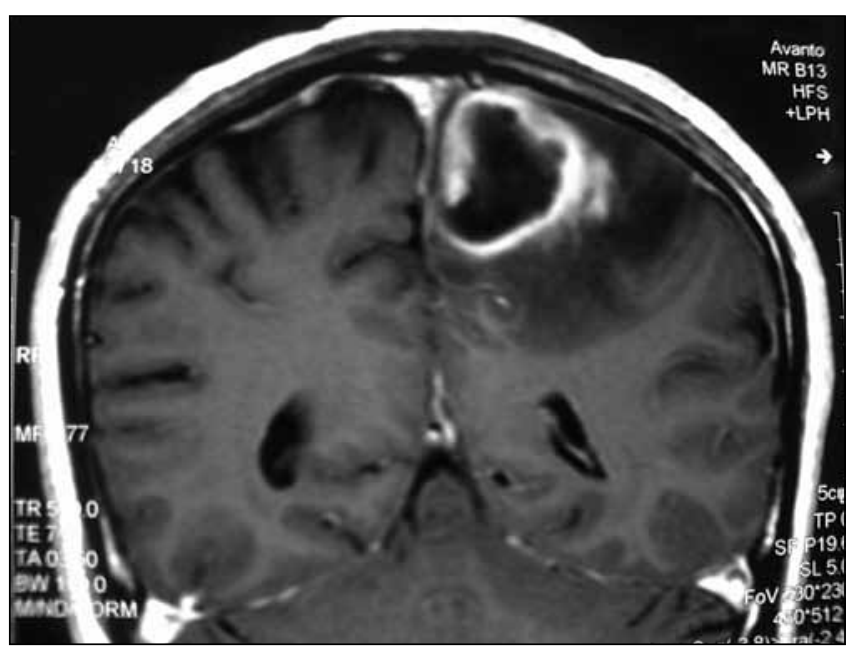

Figure 2: Abscess in the left posterior parietal lobe parasagittal location as depicted by coronal MRI brain.

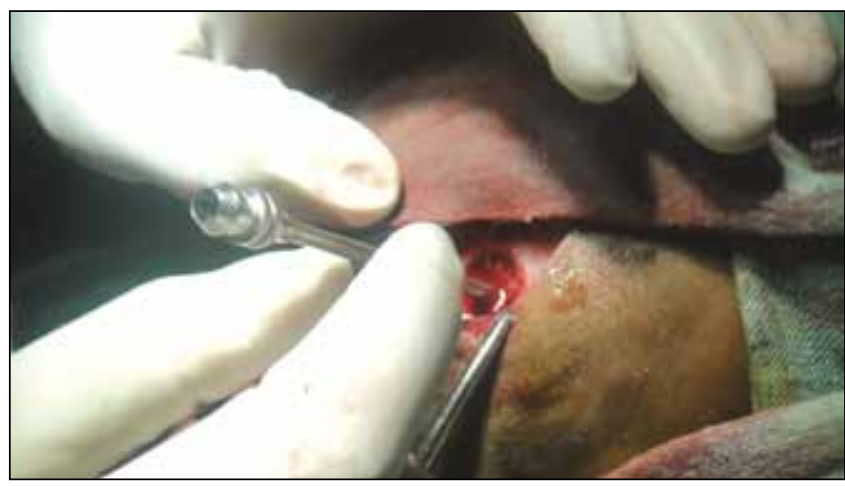

Figure 4: Brain cannula insertion to aspirate abscess cavity.
All of our patients were started on empirical I.V antibiotics which were changed to specific I.V antibiotics as soon as cultural reports were available. In $78(68.4 \%)$ patients specific I.V antibiotics were given where as in 36 (31.6\%) empirical antibiotics were continued. Majority of the patients 100 $(87.7 \%)$ received three antibiotics and in 14 patients $(12.3 \%)$ four antibiotics were used. I.V Celtriaxone + Sulbactum was

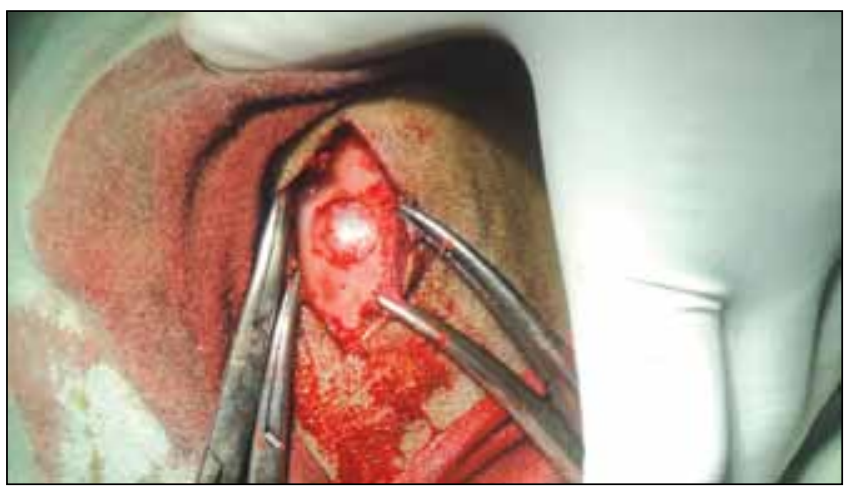

Figure 3: Burr hole for the aspiration of the brain abscess.

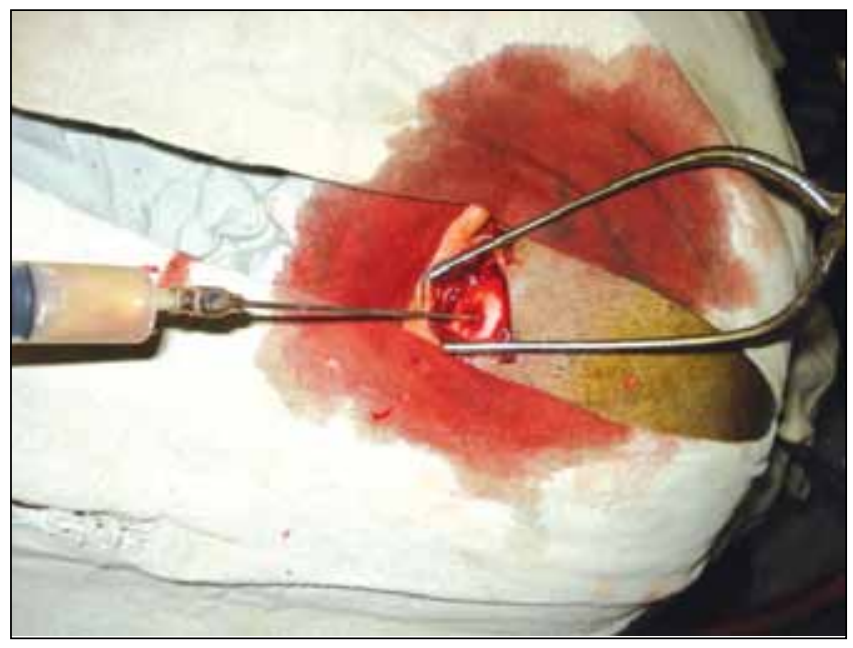

Figure 5: Pus being aspirated from the brain abscess.

Table II: Number and Location of Abscesses as Seen on CT Scan /MRI

\begin{tabular}{|c|c|c|c|c|c|c|c|c|c|c|c|}
\hline \multirow{2}{*}{ Location of abcess } & \multicolumn{2}{|c|}{ CT } & \multicolumn{2}{|c|}{ MRI } & \multicolumn{2}{|c|}{ Total } & \multirow{2}{*}{$\begin{array}{l}\text { Number of } \\
\text { Lesions }\end{array}$} & \multicolumn{2}{|c|}{$\leq 18$ (Children) } & \multicolumn{2}{|c|}{$>18$ (Adults) } \\
\hline & $\mathbf{N}$ & $\%$ & $\mathbf{N}$ & $\%$ & $\mathbf{n}$ & $\%$ & & $\mathbf{N}$ & $\%$ & $\mathbf{N}$ & $\%$ \\
\hline Frontal & 16 & 94.1 & 1 & 5.9 & 17 & 14.9 & 22 & 8 & 26.7 & 9 & 10.7 \\
\hline Temporal & 31 & 93.9 & 2 & 6.1 & 33 & 28.9 & 38 & 9 & 30.0 & 24 & 28.6 \\
\hline Parietal & 12 & 100.0 & 0 & 0.0 & 12 & 10.5 & 17 & 7 & 23.3 & 5 & 6.0 \\
\hline Occipital & 5 & 83.3 & 1 & 16.7 & 6 & 5.3 & 6 & 1 & 3.3 & 5 & 6.0 \\
\hline Temporo - parietal & 26 & 100.0 & 0 & 0.0 & 26 & 22.8 & 30 & 6 & 20.0 & 20 & 23.8 \\
\hline Parito-occipital & 7 & 77.8 & 2 & 22.2 & 9 & 7.9 & 11 & 1 & 3.3 & 8 & 9.5 \\
\hline Cerebellar & 13 & 81.3 & 3 & 18.7 & 16 & 14.0 & 16 & 1 & 3.3 & 15 & 17.9 \\
\hline Multiple places & 3 & 100.0 & 0 & 0.0 & 3 & 2.6 & 10 & 3 & 10.0 & 0 & 0.0 \\
\hline Brain Stem & 0 & 0.0 & 0 & 0.0 & 0 & 0.0 & 0 & 0 & 0.0 & 0 & 0.0 \\
\hline
\end{tabular}


used in 111 (97.4\%), Amikacin in 97 (85.1\%) patients I.V Metronidazole was used in all patients.

Table III summarizes the casautive factors, antibiotics used and type of organisms grown in culture positive patients.

It was observed that patients had wound infection 13(11.4\%) as their commonest post operative complication followed by meningitis $6(5.3 \%)$, sepsis $5(4.4 \%)$, cerebritis $2(1.8 \%)$. It was observed that at the end of study 98 (86\%) patients were surviving, 8 (7\%) patients died and 8 (7\%) were lost in follow up.

\section{DISCUSSION}

The overall incidence of pyogenic brain abscess in the developed nations is increasing with increased survival of patients with HIV, increasing number of transplant patients, and a proliferation of immunosuppressive regimens such as antineoplastic chemotherapy. The overall incidence in developing countries is felt to be higher most notably because of the endemic prevalence in some areas of tuberculosis and cysticercosis (17). Causes of brain abscesses may differ according to the socioeconomic condition of the population and geographic location as described by Hakan $\mathrm{T}$ in his observation (8). Abscesses secondary to spread from a contiguous focus of infection such as paranasal sinusitis, otitis media, mastoiditis and dental infection account for $40 \%$ to $60 \%$ of cases (25). The ear and nose infections constitute the largest group-38\% of all cases (2). Various authors have put the percentage of cryptogenic cases to around 25-38\% $(11,22)$. Beller et al. concluded that staphylococcus was by far the commonest organism cultured (63\%) followed by streptococci (20\%) (2). Louvois et al. (1977) in their study analysed Sixty-three samples of pus which were taken from the 46 patients. None of the primary samples were bacteriologically sterile; nor were 10 of the 17 samples that were taken at subsequent aspiration. The most common organisms (isolated in 36 patients) were streptococci; the most common species was streptococci milleri, which was found in 20 patients. Staphylococcus aureus was isolated from nine patients, organisms belonging to the bacteroides group from 11 patients, and enterobacteriaceae from eight patients (13). The location and predisposing condition of the abscess provide clues to the possible cause. Brain abscesses related to direct spread from sinus or odontogenic foci tend to be frontal and are caused by aerobic or anaerobic streptococci (including streptococcus milleri), enterobacteriaceae, staphylococcus aureus, and anaerobes. An abscess secondary to otic infection is usually temporal or cerebellar, with mixed flora including anaerobes and streptococci (aerobic and anaerobic), enterobacteriaceae, and pseudomonas aeruginosa. Posttraumatic brain abscess is commonly due to staphylococcus aureus, streptococci, or enterobacteriaceae. Hematogenous spread from a distant focus usually causes multiple monomicrobial abscesses in the distribution of the middle cerebral artery. Haemophilus aphrophilus is relatively common with cyanotic congenital heart disease, whereas staphylococcus aureus or streptococci are major causes in abscesses from endocarditis or prolonged bacteremia $(20,24)$.
Computed tomography is easily and widely used for confirming the diagnosis and location of the abscesses as well as for follow-up after the treatment period. It is readily available, inexpensive, and fast (10). In addition to $\mathrm{CT}$, MR imaging has contributed greatly to the evaluation of brain abscesses. Mature pyogenic brain abscesses are predominantly hypointense on T1-weighted and hyperintense on T2-weighted MR images. While they display an isointense or slightly hyperintense rim on unenhanced T1-weighted images and a hypointense rim on unenhanced T2-weighted images, they show well-defined peripheral rim enhancement on postcontrast T1-weighted images $(9,12)$. In our patients majority of the brain abscesses were supratentorial in location (94\%) which is in complete harmony with the observation made by Poffenbarger GJ et al. (17), where $85 \%$ abscesses were supratentorial. The anatomical location, number and size of abscesses, stage of abscess formation, age and neurological status of the patient can influence the strategy for managing brain abscess. In carefully selected patients (illness duration, $<2$ weeks), medical therapy alone can be successful if the following conditions are met: 1 ) the causative agent is known with a reasonably high certainty as a result of positive cultures from cerebrospinal fluid or drainage from the ear or sinuses; 2) the patient is neurologically intact; 3 ) there are no signs of increased intracranial pressure; and 4) the abscess is $<3 \mathrm{~cm}$ in diameter (5). The patient must be followed up closely clinically and radiologically when a brain abscess is managed medically (15) If there is no clinical or radiological improvement despite appropriate medical treatment, surgical treatment should be seriously considered (23).

In our study empirical antimicrobial therapy was used in all patients. The antibiotic regimen was selected according to the predisposing condition.Those antibiotics with their good CNS penetration and excellent in vitro activity against many of the pathogens that cause brain abscess, such thirdgeneration cephalosporins as cefotaxime or ceftriaxone were used widely. The combination of metronidazole and a third-generation cephalosporin was used for the treatment of abscesses originating from otitis, mastoiditis, or sinusitis, and the combination of vancomycin and a third-generation cephalosporin was used for abscesses associated with trauma or occurring after neurosurgical procedures. When the source of the infection was obscure, a third-generation cephalosporin was used in combination with both metronidazole and vancomycin. As soon as the cultre sensitivity was available patients were shifted to those antibiotics accordingly.

The mainstay of treatment for brain abscesses is a combination of antibiotic treatment and surgical intervention (14). Surgical treatment can involve either aspiration or excision of the abscess. The choice of procedure has been the subject of much debate. The advantages of aspiration are that it is simple, it can be used in the cerebritis stage, and it has less potential morbidity than surgical trauma. On the other hand, several reports have advocated excision as the procedure of choice because it is often followed by a lower incidence of recurrence and shorter hospitalization $(3,19,25)$. 
The most common surgical procedure used in our series was aspiration via a single burrhole in $58.77 \%$ patients followed by excision in $28.9 \%$ patients. In the aspiration group $28.3 \%$ patients needed aspiration more than once. Cavusoglu $\mathrm{H}$ et al. repeated aspiration more than once in 30 out $32(93 \%)$ patients who underwent aspiration in their series of 51 patients and only 10 patients underwent complete excision (5). Hakan T et al. (7) reported that in their series that $19 \%$ of their patients treated by means of aspiration underwent the procedure more than once.

Using this systematic approach we observed a mortality rate of $7 \%$ in our patients excluding the $7 \%$ other patients that were lost to follow up. The mortality rates reported for brain abscesses have varied between $0 \% 1$ (21) and > 32\%; (10) the mortality rates reported in recent large case series are in the range of $8-25 \%(1,4,6,7,16,23)$.

Table III: Causative Factors of Brain Abscess with Organisms Cultured and Antibiotics Used

\begin{tabular}{|c|c|c|c|c|c|c|c|c|c|c|c|}
\hline Factor & $\begin{array}{l}\text { Treatment } \\
\text { given }\end{array}$ & 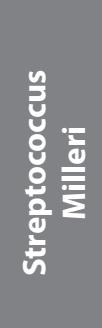 & 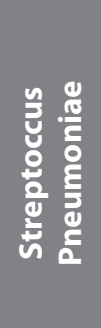 & 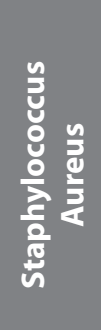 & 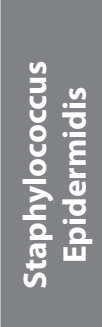 & 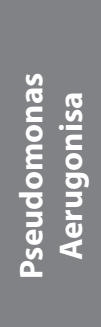 & 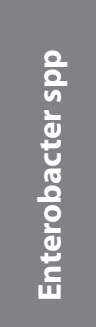 & 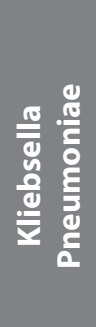 & 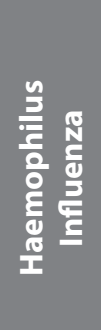 & 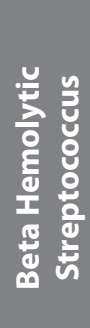 & 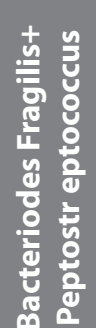 \\
\hline \multirow{8}{*}{$\mathrm{CSOM}^{*}$} & Frequency $(n=51)^{*}$ & 12 & 20 & 5 & 1 & 1 & 1 & 1 & 6 & 4 & - \\
\hline & $\begin{array}{l}\text { Ceftriaxone + } \\
\text { Sulbactum }\end{array}$ & 100.0 & 100.0 & 100.0 & 100.0 & 100.0 & 100.0 & 100.0 & 100.0 & 100.0 & - \\
\hline & Metronidazole & 100.0 & 100.0 & 100.0 & 100.0 & 100.0 & 100.0 & 100.0 & 100.0 & 100.0 & - \\
\hline & Amikacin & 100.0 & 100.0 & 80.0 & 100.0 & 100.0 & - & 100.0 & 100.0 & 100.0 & - \\
\hline & Gentamicin & - & - & - & - & - & - & - & - & - & - \\
\hline & Vancomycin & - & - & 80.0 & - & - & 100.0 & - & - & - & - \\
\hline & Pencillin G & - & - & - & - & - & - & - & - & - & - \\
\hline & Ceftazidime & - & - & - & - & 100.0 & 100.0 & - & - & - & - \\
\hline \multirow{8}{*}{ Post-traumatic } & Frequency $(n=11)$ & - & - & 4 & 2 & 2 & 2 & - & - & - & 1 \\
\hline & $\begin{array}{l}\text { Ceftriaxone + } \\
\text { Sulbactum }\end{array}$ & - & - & 100.0 & 100.0 & 100.0 & 50.0 & - & - & - & 100.0 \\
\hline & Metronidazole & - & - & 100.0 & 100.0 & 100.0 & 100.0 & - & - & - & 100.0 \\
\hline & Amikacin & - & - & 50.0 & - & 50.0 & & - & - & - & 100.0 \\
\hline & Gentamicin & - & - & - & - & - & - & - & - & - & - \\
\hline & Vancomycin & - & - & 50.0 & 100.0 & 50.0 & 100.0 & - & - & - & - \\
\hline & Pencillin G & - & - & - & - & - & - & - & - & - & - \\
\hline & Ceftazidime & - & - & - & - & 100.0 & 100.0 & - & - & - & - \\
\hline \multirow{8}{*}{$\begin{array}{l}\text { Surgery of head[VP } \\
\text { shunt,EV drain etc] }\end{array}$} & Frequency $(n=10)$ & - & - & 4 & 3 & 2 & 1 & - & - & - & - \\
\hline & $\begin{array}{l}\text { Ceftriaxone + } \\
\text { Sulbactum }\end{array}$ & - & - & 100.0 & 100.0 & 100.0 & - & - & - & - & - \\
\hline & Metronidazole & - & - & 100.0 & 100.0 & 100.0 & 100.0 & - & - & - & - \\
\hline & Amikacin & - & - & 50.0 & 33.3 & 50.0 & - & - & - & - & - \\
\hline & Gentamicin & - & - & - & - & - & - & - & - & - & - \\
\hline & Vancomycin & - & - & 50.0 & 66.7 & 50.0 & 100.0 & - & - & - & - \\
\hline & Pencillin G & - & - & - & - & - & - & - & - & - & - \\
\hline & Ceftazidime & - & - & - & - & 100.0 & 100.0 & - & - & - & - \\
\hline
\end{tabular}




\begin{tabular}{|c|c|c|c|c|c|c|c|c|c|c|c|}
\hline \multirow{8}{*}{ Cryptogenic ${ }^{* *}$} & Frequency $(n=7)^{* *}$ & - & 1 & - & - & 5 & - & - & - & - & 1 \\
\hline & $\begin{array}{l}\text { Ceftriaxone + } \\
\text { Sulbactum }\end{array}$ & - & 100.0 & - & - & 60.0 & - & - & - & - & 100.0 \\
\hline & Metronidazole & - & 100.0 & - & - & 100.0 & - & - & - & - & 100.0 \\
\hline & Amikacin & - & 100.0 & - & - & - & - & - & - & - & 100.0 \\
\hline & Gentamicin & - & - & - & - & - & - & - & - & - & - \\
\hline & Vancomycin & - & - & - & - & 100.0 & - & - & - & - & - \\
\hline & Pencillin G & - & - & - & - & - & - & - & - & - & - \\
\hline & Ceftazidime & - & - & - & - & 80.0 & - & - & - & - & - \\
\hline \multirow{8}{*}{$\begin{array}{l}\text { Pulmonary } \\
\text { disease }{ }^{* * *}\end{array}$} & Frequency $(n=5)^{* * *}$ & - & 1 & 1 & 1 & - & - & 2 & - & - & - \\
\hline & $\begin{array}{l}\text { Ceftriaxone + } \\
\text { Sulbactum }\end{array}$ & - & 100.0 & 100.0 & 100.0 & - & - & 100.0 & - & - & - \\
\hline & Metronidazole & - & 100.0 & 100.0 & 100.0 & - & - & 100.0 & - & - & - \\
\hline & Amikacin & - & 100.0 & 100.0 & 100.0 & - & - & 100.0 & - & - & - \\
\hline & Gentamicin & - & 0.0 & 0.0 & 0.0 & - & - & 0.0 & - & - & - \\
\hline & Vancomycin & - & - & 100.0 & - & - & - & - & - & - & - \\
\hline & Pencillin G & - & - & - & - & - & - & - & - & - & - \\
\hline & Ceftazidime & - & - & - & - & - & - & - & - & - & - \\
\hline \multirow{8}{*}{ Sinusitis } & Frequency $(n=6)$ & - & - & 5 & - & 1 & - & - & - & - & - \\
\hline & $\begin{array}{l}\text { Ceftriaxone + } \\
\text { Sulbactum }\end{array}$ & - & - & 100.0 & - & 100.0 & - & - & - & - & - \\
\hline & Metronidazole & - & - & 100.0 & - & 100.0 & - & - & - & - & - \\
\hline & Amikacin & - & - & 80.0 & - & 100.0 & - & - & - & - & - \\
\hline & Gentamicin & - & - & - & - & - & - & - & - & - & - \\
\hline & Vancomycin & - & - & 40.0 & - & - & - & - & - & - & - \\
\hline & Pencillin G & - & - & - & - & - & - & - & - & - & - \\
\hline & Ceftazidime & - & - & - & - & 100.0 & - & - & - & - & - \\
\hline \multirow{8}{*}{$\begin{array}{l}\text { Adjacent local } \\
\text { cranial infection }\end{array}$} & Frequency $(n=3)$ & - & - & 1 & 2 & - & - & - & - & - & - \\
\hline & $\begin{array}{l}\text { Ceftriaxone + } \\
\text { Sulbactum }\end{array}$ & - & - & 100.0 & 100.0 & - & - & - & - & - & - \\
\hline & Metronidazole & - & - & 100.0 & 100.0 & - & - & - & - & - & - \\
\hline & Amikacin & - & - & 100.0 & - & - & - & - & - & - & - \\
\hline & Gentamicin & - & - & - & - & - & - & - & - & - & - \\
\hline & Vancomycin & - & - & - & 100.0 & - & - & - & - & - & - \\
\hline & Pencillin G & - & - & - & - & - & - & - & - & - & - \\
\hline & Ceftazidime & - & - & - & - & - & - & - & - & - & - \\
\hline
\end{tabular}

* In the CSOM group total number of patients were 57 however only 51 were culture positive (as shown in the Table III) and received antibiotics as per the culture reports 6 remaining culture negative patients received empirical antibiotics through full course of treatment.

** In the cryptogenic group total number of patients were 10 however only 7 were culture positive (as shown in the Table III) and received antibiotics as per the culture reports 3 remaining culture negative patients received empirical antibiotics through full course of treatment.

*** In the pulmonary disease group total number of patients were 8 however only 5 were culture positive (as shown in the Table III) and received antibiotics as per the culture reports 3 remaining culture negative patients received empirical antibiotics through full course of treatment

All patients in heart disease group were culture negative and were not included in the Table III and as such received empirical treatment only. 


\section{REFERENCES}

1. Auvichayapat $\mathrm{N}$, Auvichayapat $\mathrm{P}$, Aungwarawong S: Brain abscess in infants and children: A retrospective study of 107 patients in Northeast Thailand. J Med Assoc Thai 90: 1601-1607, 2007

2. Beller AJ, Sahar A, Praiss I: Brain abscess; Review of 89 cases over a period of 30 years. Journal of Neurology, Neurosurgery, and Psychiatry 36:757-768,1973

3. Bidzinski J, Koszewski W: The value of different methods of treatment of brain abscess in the CT era. Acta Neurochir (Wien)105:117-120, 1990

4. Carpenter J, Stapleton S, Holliman R: Retrospective analysis of 49 cases of brain abscess and review of the literature. Eur J Clin Microbiol Infect Dis 26:1-11, 2007

5. Cavusoglu H, Kaya RA, Turkmenoglu ON, Colak I, Aydin Y: Brain abscess: Analysis of results in a series of 51 patients with a combined surgical and medical approach during an 11-year period. Neurosurg Focus 24(6):E9, 2008

6. Goodkin HP, Harper MB, Pomeroy SL: Intracerebral abscess in children: Historical trends at Children's Hospital Boston. Pediatrics 113:1765-1770, 2004

7. Hakan T, Ceran N, Erdem I, Berkman MZ, Goktas P: Bacterial brain abscesses: An evaluation of 96 cases. J Infect 52(5): 359-366, 2006, Epub 2005 Sep 23

8. Hakan T: Management of bacterial brain abscesses. Neurosurgical FOCUS 24(6):E4, 2008

9. Haimes $A B$, Zimmerman RD, Morgello S, Weingarten $K$, Becker $R D$, Jennis R, Deck MD: MR imaging of brain abscesses. AJR Am J Roentgenol 152:1073-1085, 1989

10. Kao PT, Tseng HK, Liu CP, Su SC, Lee CM: Brain abscess: Clinical analysis of 53 cases. J Microbiol Immunol Infect 36: 129-136, 2003

11. Lu CH, Chang WN, Lui CC: Strategies for the management of bacterial brain abscess. J Clin Neurosci 13(10):979-985, 2006, Epub 2006 Oct 23

12. Luthra G, Parihar A, Nath K, Jaiswal S, Prasad KN, Husain $N$, Husaine $M$, Singhe $S$, Beharib S, Guptaa RK: Comparative evaluation of fungal, tubercular, and pyogenic brain abscesses with conventional and diffusion MR imaging and proton MR spectroscopy. AJNR Am J Neuroradiol 28:1332-1338, 2007
13. Louvois J D, Gortvai P, Hurley R: Bacteriology of abscesses of the central nervous system: A multicentre prospective study. British Medical Journal 2:981-984,1977

14. Lee TH, Chang WN, Su TM, Chang HW, Lui CC, Ho JT, Wang $\mathrm{HC}$, Lu CH: Clinical features and predictive factors of intraventricular rupture in patients who have bacterial brain abscesses. J Neurol Neurosurg Psychiatry 78:303-309, 2007

15. Osenbach RK, Loftus CM: Diagnosis and management of brain abscess. Neurosurg Clin N Am 3:403-420, 1992

16. Prasad KN, Mishra AM, Gupta D, Husain N, Husain M, Gupta RK: Analysis of microbial etiology and mortality in patients with brain abscess. J Infect 53:221-227, 2006

17. Poffenbarger GJ, Khajavi K: Management of solitary intracranial abscess, in Batjer HH, Loftus CM (eds): Textbook of Neurological Surgery. Principles and Practice. Philadelphia: Lippincott Williams and Wilkins, 2003:3142-3150

18. Schmidek $\mathrm{HH}$ : Supparative intracranial infections. In; Schmidek HH, Roberts WD (eds): Operative Neurosurgical Techniques, Indications Methods and Results, Fifth ed. Philedelphia: Saunders Elsevier, 2006:1591-1599

19. Stephanov S: Surgical treatment of brain abscess. Neurosurgery 22(4):724-730, 1988

20. Spinnato S, Mazza C, Bricolo A: Nonoperative treatment of cerebellarabscesses. A case report and review of the literature. Childs Nerv Syst 14:606-609, 1998

21. Tekkok IH, Erbengi A: Management of brain abscess in children: Review of 130 cases over a period of 21 years. Childs Nerv Syst 8:411-466, 1992

22. Tseng MY:Brain abscess in 142 patients: Factors influencing outcome and mortality Surg Neurol. 65(6):557-62; discussion 562.jun 2006

23. Xiao F, Tseng MY, Teng LJ, Tseng HM, Tsai JC: Brain abscess: Clinical experience and analysis of prognostic factors. Surg Neurol 63:442-450, 2005

24. Yogev R, Bar-Meir M: Management of brain abscesses in children. Pediatr Infect Dis J 23:157-159, 2004

25. Yang SY: Brain abscess: A review of 400 cases. J Neurosurg 55:794-799, 1981 